\title{
NOTES
}

\section{LABOR VIOLENCE AND THE HOBBS ACT: A JUDICIAL DILEMMA*}

THREATS, force and violence obstructing interstate commerce transform union power from a favorite to a problem of the law. ${ }^{1}$ Threats of work stoppages may be employed to enrich individual labor racketeers through extortion of protection payments. ${ }^{2}$ Alternatively, intimidation may be utilized to accomplish union aims which are illegal or inconsistent with national labor policies. ${ }^{3}$ Compensation for unneeded services represents a flagrant example. ${ }^{4}$ Of course,

*United States v. Nedley, 153 F. Supp. 887 (W.D. Pa. 1957).

1. For discussion of the favorable treatment accorded unions by, e.g., the NorrisLaGuardia Act, see Note, 67 YALE L.J. $98-99$ n.2 (1957). On the Supreme Court's role in the labor field generally, see Summers, Frankfurter, Labor Lawe and the Judge's Function, 67 YALE L.J. 266 (1957).

2. See, e.g., Callanan v. United States, 223 F.2d 171 (8th Cir. 1955) ; Hulahan v. United States, 214 F.2d 441 (8th Cir.), cert. deried, 348 U.S. 856 (1954) ; United States v. Compagna, 146 F.2d 524 (2d Cir. 1944), cert. denied, 324 U.S. 867 (1945); Nick v. United States, 122 F.2d 660 (8th Cir.), cert. denied, 314 U.S. 687 (1941). See also Hearings Before Subcommittee No. 3 of the House Committee on the Judiciary, 77th Cong., 2d Sess., ser. 17 (1942) ; Barbash, The Practice of Unionism 306-23 (1956).

3. Various union aims are illegal under state laws. E.g., ARK. STAT. ANn. §§ 81-201 to -205 (Supp. 1957) (closed shop); GA. CODE ANN. § 54-906 (Supp. 1955) (compulsory checkoff of union dues). Others are proscribed by the National Labor Relations Act. 49 STAT. 449 (1935), as amended, 29 U.S.C. \$§ 151-68 (1952), as amended, 29 U.S.C. \$ 154(a) (Supp. IV, 1957). Thus, strikes and boycotts are declared unfair when one of their objects is to: (1) force an employer or self-employed person to join a union; (2) force an employer to "cease using, selling, handling, transporting or otherwise dealing in" the products of another employer, or to "cease doing business with" any other person; (3) force any other employer to recognize or bargain with a union unless such union has been certified by the NLRB; (4) force an employer to bargain with one union when another union has already been certified as the employees' representative; (5) force an employer to assign particular work projects to one union instead of another. 61 STAT. 141 (1947), 29 U.S.C. $\S 158$ (b) (4) (1952). For other union unfair labor practices, see Taft-Hartley Act $\S 8(b)$, 61 STAT. 141 (1947), 29 U.S.C. \$ 158 (b) (1952).

Such unfair strikes are often a breeding place for violence. See Curto v. ILU, $107 \mathrm{~F}$. Supp. 805 (D. Ore. 1952) (secondary boycott).

4. See United States v. Local 807, Int'1 Brotherhood of Teamsters, 315 U.S. 521 (1942); United States v. Kemble, 198 F.2d 889 (3d Cir.), cert. denied, 344 U.S. 893 (1952). "Featherbedding" is usually an expression of resistance to technological change and threatened unemployment. Aaron, Governmental Restraints on Featherbedding, 5 Stan. L. Rev. 680 (1953); Note, 34 CoRnell L.Q. 255 (1948).

Discouraging "featherbedding" was the object of several federal statutory provisions. The Lea Act (constitutionality upheld in United States v. Petrillo, 332 U.S. 1 (1947), 16 GEO. WASH. L. REv. 2S2 (1948)) was aimed at outlawing musician union practices of requiring stand-ins when "canned music" was used in broadcasting. 60 STAT. 89 (1946), 47 U.S.C. $\$ 506$ (1952) ("Anti-Petrillo Act"). And $\S 8(b)(6)$ of Taft-Hartley classifies demanding payment for services not performed as a union unfair labor practice. 61 STAT. 
threats and violence have also served to support strikes and other legitimate union activities. ${ }^{5}$ Whatever their design, these strong-arm tactics have not been adequately suppressed by state statutes and federal labor legislation. States often lack laws adapted to meet the particular problems of labor violence. ${ }^{6}$ Strict enforcement by state authorities of such laws as do exist may be discouraged by organized labor's political and financial strength. ${ }^{7}$ Even diligent

142 (1947), 29 U.S.C. $\$ 158$ (b) (6) (1952). This provision may be of limited utility, however. Van de Water, Control of Featherbedding by the Secondary Boycott Ban, 6 LAB. L.J. 633 (1955). See American Newspaper Publishers Ass'n v. NLRB, 345 U.S. 100 (1953).

On the general desirability of laws against featherbedding, see Wood, The Wisdom of Outlawing Featherbedding, 6 LAB. L.J. 821 (1955) ; Notes, 52 CoLdM. L. Rev. 1020 (1952), 34 CoRNell L.Q. 255 (1948) ; Labor ReLATIONS AND tHE LAw 697-98 (Mathews ed. 1953).

5. See NLRB v. International Rice Milling Co., 341 U.S. 665 (1951) ; NLRB v. Deena Artware, Inc., 198 F.2d 645 (6th Cir. 1952), cert. denied, 345 U.S. 906 (1953) ; United Furniture Workers, CIO, 81 N.I.R.B. 886 (1949). That union violence against employees may be an unfair labor practice under Taft-Hartley Act $\$ 8$ (b) (1) (A), 61 STAT. 141 (1947), 29 U.S.C. $\$ 158$ (b) (1) (A) (1952), does not imply that the strike itself is either illegal or "unfair."

For a general treatment of the rationale and background of labor violence, see Labor Violence and Corruption, Business Week, Aug. 31, 1957, p. 77.

6. Brown, State Legislative Protection from Labor Violence and Caercion, 4 LAB. L.J. 822 (1953).

Some states have criminal laws directed at the types of violence which may arise out of labor disputes. See, e.g., FLA. STAt. AnN. \$ 447.09 (Supp. 1956) (coercion and disorderly picketing) ; Ky. REv. STAT. ANN. $\$ \S 433.370$, 433.380 (Baldwin 1955) (obstruction of transportation); N.Y. PEN. LAw $\$ 530$ (coercion); TEx. Rev. Civ. Stat. ANN. art. 5154d (Supp. 1956) (mass picketing). See also 4 CCH LAB. L. REP. If 41501-65 (1957). But for the most part, criminal control of labor violence rests with common-law offenses such as assault, breach of peace, unlawful assembly and affray. See, e.g., Illinois v. Guzzardo, 4 Ill. App. 2d 355, 124 N.E.2d 39 (1955) ; Carr v. Tennessee, 30 CCH Lab. Cas. IT 70108 (Tenn. 1956).

Of course, "the power of state and local authorities to punish acts of violence is beyond question. It is not diminished or affected by the circumstance that the violence may be the outgrowth of a labor dispute." United States v. Local 807, Int'1 Brotherhood of Teamsters, 315 U.S. 521, 536 (1942). In addition to criminal law, states have the power to enjoin union violence, even when the violent conduct is an unfair labor practice. UAW v. Wisconsin Employment Relations Bd., 351 U.S. 266 (1956), 42 IowA L. Rev. 137; Allen-Bradley Local 11.11, United Elec. Workers v. Wisconsin Employment Relations Bd., 315 U.S. 740 (1942); The Supreme Court, 1955 Term, 70 Harv. L. Rev. 83, 173-74 (1956). And state jurisdiction to grant damages for torts involving violence is not preempted by TaftHartley. United Constr. Workers v. Laburnum Constr. Corp., 347 U.S. 656 (1954), 54 ColuMr. L. REv. 1147.

On state laws dealing with labor, see, generally, Comen, State Labor Legislation 1937-1947 (1948).

7. See Barbash, The Practice of Untonism 248, 319-20 (1956); N.Y. Times, Dec. 7,1957, p. 13, col. 1 ("political pressures" indicated by witnesses at Senate investigations; investigators report evidence of "bribery") ; 91 CoNg. REc. 11904 (1945) (statement of Rep. Gwynne: "break-down of law enforcement reminding the Congress of its duty to protect interstate commerce") ; $i d$. at 11909-10 (statement of Rep. Summers to same effect); Hearings, supra note 2 , at 189-90. 
local officials are not equipped to cope with major outbreaks of violence. ${ }^{8}$ Federal civil regulation under the Taft-Hartley Act has also proved insufficient. ${ }^{9}$ Unless the particular interference with commerce is an unfair labor practice, the act provides no remedy. ${ }^{10}$ And since unfair labor practices can only be committed by employers, unions or their agents, ${ }^{11}$ application of the act will be barred, absent a showing of union authority. ${ }^{12}$ Furthermore, such sanctions as may be imposed are often inadequate; for violations will only result in cease and desist orders applying to future conduct. ${ }^{13}$

Federal criminal regulation was expanded in 1946 with the enactment of the Hobbs Anti-Racketeering Act. ${ }^{14}$ While the legislative history indicates that

8. See Hearings, supra note 2 , at $370-71,426$.

9. Labor Management Relations Act, 1947, 61 STAT. 136 (1947), 29 U.S.C. \$§ 141-97 (1952), as amended, 29 U.S.C. $\S \S 154(a), 172,188$ (Supp. IV, 1957).

10. NLRB v. International Rice Milling Co., 341 U.S. 665 (1951) ; NLRB v. Furriers Joint Council, 224 F.2d 78 (2d Cir. 1955). "While the Federal Board is empowered to forbid a strike, when and because its purpose is one that the Federal Act made illegal, it has been given no power to forbid one because its method is illegal-even if the illegality were ... actual or threatened violence to persons or destruction of property." International Union, UAW, AFL v. Wisconsin Employment Relations Bd., 336 U.S. 245, 253 (1949). See 61 StaT. 140 (1947), 29 U.S.C. \& 158 (1952) (defining unfair labor practices); 61 STAT. 146 (1947), 29 U.S.C. $\$ 160$ (1952) (remedies for unfair labor practices).

11. 61 Stat. 140 (1947), 29 U.S.C. $\S 158$ (a) (1952) (employers); 61 STAT. 141 (1947), 29 U.S.C. $\$ 158$ (b) (1952) (unions or their agents).

12. Lumber and Sawmill Workers Union, AFL, 87 N.L.R.B. 937 (1949); National Union of Marine Cooks, CIO, 87 N.L.R.B. 54 (1949); Perry Norvell Co., 80 N.L.R.B. 225 (1948) ; Taft-Hartley Act § 2(13), 61. STAT. 139 (1947), 29 U.S.C. \$ 152(13) (1952); Petro, Concerted Activities-Protected and Unprotected-II, 2 LAB. L.J. 3 (1951); Devclopments in the Law-The Taft-Hartley Act, 64 HARv. L. REv. 781, 797-98 (1951). See also Note, 63 Harv. L. Rev. 1035 (1950); 16 U. CHI. L. Rev. 575 (1949).

13. Taft-Hartley Act $\S \S 10$ (c), (e), 61 Stat. 147 (1947), 29 U.S.C. $\S \S 160$ (c), (e) (1952). See Lloyd Reisner, 112 N.L.R.B. 17 (1955); United Furniture Workers, CIO, 81 N.L.R.B. 886 (1949); International Longshoremen's Union, CIO, 79 N.L.R.B. 1487 (1948).

Employers may fire or refuse to reinstate employees who took part in violence. See NLRB v. Fansteel Metallurgical Corp., 306 U.S. 240 (1939) ; NLRB v. Ohio Calcium Co., 133 F.2d 721 (6th Cir. 1943).

14. 60 Stat. 420 (1946) (revised by 62 Stat. 793 (1948), 18 U.S.C. $\$ 1951$ (1952)). Section 1951 relevantly reads:

"Interference with commerce by threats or violence.

"(a) Whoever in any way or degree obstructs, delays, or affects commerce or the movement of any article or commodity in commerce, by robbery or extortion or attempts or conspires so to do, or commits or threatens physical violence to any person or property in furtherance of a plan or purpose to do anything in violation of this section shall be fined not more than $\$ 10,000$ or imprisoned not more than twenty years, or both.

"(b) As used in this section-

"(1) The term 'robbery' means the unlawful taking or obtaining of personal property from the person or in the presence of another, against his will, by means of actual or threatened force, or violence, or fear of injury, immediate or future, to his person or property, or property in his custody or possession, or the person or property of a 
the primary purpose was elimination of extortion by threats or force, ${ }^{15}$ the act also proscribes interference with commerce by robbery. ${ }^{16}$ Since the definition of robbery did not mirror existing statutory and common-law language, the act's coverage remained undefined. ${ }^{17}$ Limited to extortion prosecutions for "featherbedding" or "protection money" demands, ${ }^{18}$ the cases had neither

relative or member of his family or of anyone in his company at the time of the taking or obtaining.

“(2) The term 'extortion' means the obtaining of property from another, with his consent, induced by wrongful use of actual or threatened force, violence, or fear, or under color of official right."

The 1946 statute amended an earlier anti-racketeering act, Act of June 18, 1934, c. 569, 48 STAT. 979.

On the congressional desire for uniform protection of interstate commerce, see, c.g., 91 Cong. Rec. 11900 (1945) (Rep. Hancock); id. at 11911 (Rep. Jennings); H.R. ReP. No. 238, 79th Cong., 1st Sess. 10 (1945).

15. Enactment of the Hobbs Act was motivated by the Supreme Court's decision in United States v. Local 807, Int'1 Brotherhood of Teamsters, 315 U.S. 521 (1942). United States v. Green, 350 U.S. 415, 418 (1956) ; United States v. Kemble, 198 F.2d 889 (3d Cir.), cert. denied, 344 U.S. 893 (1952) ; Fed. Legis., 35 GEo. L.J. 362 (1947). In Local 807, teamsters had stationed themselves at the mouth of the Holland Tunnel and forced every truck to take on a "helper" and pay him a day's wages. The Court held this action a demand for bona fide wages and hence immune from the operation of the 1934 anti-racketeering act. This holding was felt to emasculate the 1934 law and gave rise to a storm of protest. See congressional debates on the Hobbs Act. 91 CoNG. Rec. 11899-922 (1945).

16. 18 U.S.C. $\$ 1951$ (1952), note 14 supra.

17. Common-law robbery is the taking and carrying away, with intent to deprive the owner permanently, "of the personal property of another, from his person or in his presence, by violence or intimidation, against his will." MILLER, CRnIINAL LAw $\$ \$ 123-24$ (1934). While the carrying away requirement is not explicit in all state statutes, it has been retained as an element of robbery by the courts. Thus, robbery under the New York statute has been held a form of larceny, and carrying away is an essential element of that crime. See People v. Levan, 295 N.Y. 26, 64 N.E.2d 341 (1945). The Hobbs Act incorporated, but with some changes, the New York Penal Code's robbery definition. 91 Cong. REc. 11900 (1945) (statement of Rep. Hobbs). Compare the Hobbs Act $\$$ (b) (1), note 14 supra, with N.Y. PEN. LAW $\$ 2120$. The use of obtaining as well as taking in Hobbs could be considered so to change the common law that carrying away would not be required. For fuller discussion of the similarities and differences between the Hobbs Act, the N.Y. Code and the common-law definitions, see notes 26-31, 33 infra.

No legislative history suggests the situations in which Congress intended the robbery provision to be applied.

18. Cases arising under the Hobbs Act and its predecessor include: United States v. Green, 350 U.S. 415 (1956), on remand, 246 F.2d 155 (7th Cir. 1957) (coerced payments for "imposed, unwanted, superfluous and fictitious services") ; United States v. Lacal 807, Int'l Brotherhood of Teamsters, 315 U.S. 521 (1942) (truckers forced to hire unnecessary "helpers") ; United States v. Postma, 242 F.2d 488 (2d Cir.), cert. denicd, 354 U.S. 922 (1957) (payment to union leaders on threat of strike) ; Schmidt v. United States, 237 F.2d 542 (Sth Cir. 1956) (extortion by threats of physical violence); United States v. Masiello, 235 F.2d 279 (2d Cir.), cert. denied, 352 U.S. 882 (1956) (payment to union officers on threat of losing union contracts); United States v. Lowe, 234 F.2d 919 (3d Cir.), cert. denied, 352 U.S. 838 (1956) (extortion); United States v. Floyd, 228 F.2d 913 (7th Cir.), cert. denied, 351 U.S. 938 (1956) (payment to union officers on threat of forcing employ- 
clarified the robbery provision nor indicated the extent to which violence occurring in the course of legitimate union activities might be subject to the act's strictures. ${ }^{19}$

In United States $v$. Nedley, the robbery clause, broadly construed, was applied to conduct incidental to union activity not in itself illegitimate. ${ }^{20}$ During a labor dispute between Pittsburgh department stores and the teamsters union, defendants were stationed on the roads to insure union members' compliance with the strike order. ${ }^{21}$ An independent trucker and his helper, en route to a struck department store, were threatened and sought police protection. ${ }^{22}$ When the police escort withdrew, the four defendants allegedly stopped the truck, forced the driver and his helper out and attacked them. ${ }^{23}$ Defendants

ment of unnecessary workers); United States v. Varlack, 225 F.2d 665 (2d Cir. 1955) (extortion by threat of work stoppage); United States v. Dale, 223 F.2d 181 (7th Cir. 1955) (extortion by threat of strikes); Callanan v. United States, 223 F.2d 171 (8th Cir. 1955) (payment to union officer on threat of strike) ; Bianchi v. United States, 219 F.2d 182 (Sth Cir.), cert. denied, 349 U.S. 915 (1955) (payment to union officers on threat of physical violence to property and person); Hulahan v. United States, 214 F.2d 441 (Sth Cir.), cert. denied, 348 U.S. 856 (1954) (payment to union officer on threat of "labor trouble"); United States v. Kemble, 198 F.2d 889 (3d Cir.), cert. denied, 344 U.S. 893 (1952) (truckers prevented from unloading without hiring union "helpers"); Ladner v. United States, 168 F.2d 771 (5th Cir.), cert. denied, 335 U.S. 827 (1948) (deputy sheriff demanding payment from truck drivers in return for failure to prosecute law violations); United States v. Compagna, 146 F.2d 524 (2d Cir. 1944), cert. denied, 324 U.S. S67 (1945) (payments to union officers on threat of strikes); Nick v. United States, 122 F.2d 660 (Sth Cir.), cert. denied, 314 U.S. 687 (1941) (inflated wage demands used to extort personal payments to union officers); United States v. Malinsky, 19 F.R.D. 426 (S.D.N.Y. 1956) (extortion) ; United States v. Bioff, 40 F. Supp. 497 (S.D.N.Y. 1941) (extortion); United States v. Gramlich, 19 F. Supp. 442 (S.D. I1l. 1937) (interference with interstate commerce); United States v. McGlone, 19 F. Supp. 285 (E.D. Pa. 1937) (indictment for extortion on threat of work stoppage).

For the statute's operation against racketeering in general, see Brown \& Peer, The Anti-Rackcteering Act: Labor and Management Weapon Against Labor Racketeering, 32 N.Y.U.L. Rev. 965 (1957) ; Brownell, Federal Suppression of Labor Racketeering: $A$ Report, 9 Sw. L.J. 341 (1955) ; Labor Racketeering, Fortune, July 1955, p. 50.

19. For critical commentaries on this aspect of the Hobbs Act, see Note, 101 U. PA. L. Rev. 1030 (1953) ; Fed. Legis., 35 Geo. L.J. 362 (1947). The possibility of unduly restricting legitimate labor activities troubled the judges of the Third Circuit in United States v. Kemble, supra note 18, 66 HARv. L. Rev. 926 (1953), 28 N.Y.U.L. Rev. 436 (1953).

However, the Hobbs cases often contain broad statements about the inapplicability of the act to lawful activities. E.g.: "The Anti-Racketeering Act does not curtail any legitimate labor activities.... [The statute does not apply to] 'action by a labor organization leader, honestly acting and representing members of his organization.' "Callanan v. United States, stipra note 18 , at 175 .

20. 153 F. Supp. 887 (W.D. Pa. 1957). No unfair labor practice was shown. The incident involved probably would not constitute a secondary boycott under Taft-Hartley $\S \delta(b)(4)$, since the truckers were not induced to engage in a "concerted" refusal to transport goods. NLRB v. International Rice Milling Co., 341. U.S. 665 (1951).

21. $153 \mathrm{~F}$. Supp. at $\$ 90$.

22. Ibid.

23. Ibid. 
were indicted under the Hobbs Act for interference with commerce by robbery, and three were convicted. ${ }^{24}$

In overruling motions for acquittal and new trial, the court held defendants' actions within the statutory definition of robbery. It admitted that they would not have been guilty of robbery in most states and at common law. ${ }^{25}$ No intention permanently to deprive the owner of possession was shown. ${ }^{26}$ Nor were the requirements of a "taking" or "asportation" met. ${ }^{27}$ Yet the court argued that the statute explicitly exceeded the common law. ${ }^{28}$ In defining robbery, Hobbs added "obtaining" of property to the common-law "taking."20 Similarly, the court stated, the types of coercion making deprivation of property robbery were substantially broadened. ${ }^{30}$ And, intent permanently to exclude the owner from possession was nowhere mentioned in the statute. ${ }^{31}$ While the court

24. One of the three was convicted on a conspiracy count. $I d$. at 889 .

25. See note 17 supra.

26. Common-law robbery, as incorporated into most state criminal statutes, required an intent to steal-animus furandi. This requirement has been construed as intent to deprive the owner permanently of his property. Green v. Commonwealth, $133 \mathrm{Va} .695,112$ S.E. 562 (1922) ; Connecticut v. Sawyer, 95 Conn. 34, 110 Atl. 461 (1920) (larceny); Mirler, Criminal Law § 114 (1934).

27. The common-law offense required "taking" and "asportation." Rivers v. State, 46 Ga. App. 778, 169 S.E. 260 (1933); Green v. Commonwealth, supra note 26. Taking is the "securing of dominion or absolute control over the property"; asportation is carrying it away. Miller, Criminal Law § 113 (1934).

28. $153 \mathrm{~F}$. Supp. at 891 . See note 17 supra and accompanying text. In particular, the court relied on United States v. De Normand, 149 F.2d 622 (2d Cir.), cert. denicd, 326 U.S. 756 (1945) (holding "stealing," under the statutory crime of stealing from interstate commerce, now 62 STAT. 729 (1948), 18 U.S.C. $\$ 659$ (1952), to be broader than commonlaw larceny).

A federal statutory definition of a crime may alter or replace the common-law definition. United States v. Turley, 352 U.S. 407 (1957) ; Boone v. United States, 235 F.2d 939 (4th Cir. 1956) ; United States v. O'Connell, 165 F.2d 697 (2d Cir.), cert. denied, 333 U.S. 864 (1948); United States v. Handler, 142 F.2d 351 (2d Cir.), cert. denied, 323 U.S. 741. (1944). But minor changes in wording need not signify a departure from the common law. See Ross v. Jones, 89 U.S. (22 Wall.) 576, 591 (1875) ; United States v. Thomas, 82 U.S. (15 Wall.) 337, 345 (1873).

29. Compare the Hobbs Act $\S$ (b) (1), note 14 supra, with common-law definition, note 17 supra. Why "obtaining" was added is unclear. See ibid. The distinction may be tenuous. See N.Y. PEN. LAw § 2121 (employing "obtaining" as equivalent to "taking").

30. This assertion lacks support. The Hobbs Act $\S$ (b) (1), note 14 supra, only adds "actual or threatened" to the "force, or violence, or fear of injury" language of N.Y. PEN. LAw \& 2120. The common-law concept of coercion is not thereby altered. See Bloomer v. People, 1 Abb. App. Dec. 146 (N.Y. 1866).

31. Hobbs Act $\S$ (b) (1), note 14 supra. N.Y. PEN. LAW $\S 2120$ also has no explicit intent requirement. But the New York courts have held that robbery is essentially larceny by force from the person and that larceny includes a specific intent to steal. People v. Levan, 295 N.Y. 26, 64 N.E.2d 341 (1945). The Nedley court apparently ignored the fact that the Hobbs definition was substantially taken from the New York Penal Law. See note 33 infra.

The absence of animus furandi is the Nedley robbery definition's most significant and most novel deviation from the common law. With Nedley, compare United States v. De 
recognized that even the obtaining of property required possession by defendants, it ruled that stopping a truck and using physical violence to eject the occupants met the requirement. ${ }^{32}$ This broad construction of robbery was employed even though it necessitated distortion of criminal law categories ${ }^{33}$ and threatened to impede legitimate union activities. ${ }^{34}$

Nevertheless, certain violent obstructions of interstate commerce would not fall within even the expanded robbery concept of the Nedley holding. The requirement that "property" be "obtained" gives rise to these situations. For example, use of physical violence against persons not then in control of property, as when union agents assault nonstrikers about to unload cargo, would not violate the statute. ${ }^{35}$ Nor would Hobbs punish interferences with movement of property when possession is not obtained, as in the case of a plant entrance blockade. ${ }^{36}$ But both of these factual patterns would be covered by the

Normand, 149 F.2d 622 (2d Cir.), cert. denied, 326 U.S. 756 (1945) (holding asportation and actual possession unnecessary to constitute "stealing").

32. The court observed that possession, a prerequisite to robbery, may be actual or constructive. 153 F. Supp. at 891 , citing Le Fanti v. United States, 259 Fed. 460 (3d Cir. 1919). It concluded that defendants gained constructive, if not actual, possession of the truck. 153 F. Supp. at 891. For a similar use of constructive possession, see United States v. De Normand, supra note 31, wherein defendants seized and bound truck drivers coming out of a restaurant and were arrested when walking toward the trucks. Although no physical contact was made with the trucks, the court held that defendants had constructive possession and that asportation was not an element of the statutory crime of stealing goods in interstate commerce.

33. See notes 25-32 supra and accompanying text.

While the court's interpretation is possible, it does not seem inevitable. New York courts, faced with a similar statute, have reached a different result. People v. Levan, 295 N.Y. 26, 64 N.E.2d 341 (1945). In deviating from common-law concepts, the Nedley holding probably contravened congressional intent. In House debate, for example, the offense was generally referred to as "robbery," without indication that an unusual meaning was to be inferred. 91 CoNG. Rec. 11899-922 (1945). The author of the bill stated: "[T] here is nothing clearer than the definitions of robbery and extortion in this bill. They have been construed by the courts not once, but a thousand times. The definitions in this bill are copied from the New York Code substantially ...." Id. at 11900 (statement of Rep. Hobbs). And another congressman pointed out that the definitions of robbery and extortion are "practically the same as the statutes in the different States of the Union." Id. at 11910 (statement of Rep. Springer). In the hearings on the bill, Rep. Hobbs stated that "the elements of the crime denounced by this bill are essentially the same as the elements of robbery or extortion," and that he considered simply using "robbery or extortion in haec verba." Hearings, supra note 2, at 427. But see statement of Rep. Emmanuel Celler, who described the statutory definitions as "so broad as to permit one to drive a coach and six through them." 91 Cosv. Rec. 11901 (1945).

34. See notes $45-46,48$ infra and accompanying text.

35. See Curto v. ILU, 107 F. Supp. 805 (D. Ore. 1952).

36. See NLRB v. International Rice Milling Co., 341 U.S. 665 (1951) ; United Furniture Workers, CIO, 81 N.L.R.B. 886 (1949) ; International Longshoremen's Union, CIO, 79 N.L.R.B. 1487 (1948). For indications that obstruction of access may constitute a "seizure" of plant property, see Westinghouse Elec. Corp. v. UEW, $353 \mathrm{~Pa} .446,455$, 46 A.2d 16, 20 (1946) (pickets blocking entrances): "[I]t is obvious that the seizure 
court's suggestion in dictum that the clause, "or commits or threatens physical violence ... in furtherance of a plan or purpose to do anything in violation of this section," be read in the disjunctive with the terms "robbery or extortion."37 So construed, the act would make it criminal to commit or threaten "physical violence to any person or property in furtherance of a plan or purpose to obstruct, delay, or affect commerce or the movement of any article or commodity in commerce, in any way or degree."38

This construction, however, seems unwarranted. The current version of Hobbs, ${ }^{39}$ rephrasing the original 1946 law, ${ }^{40}$ was passed in 1948 as part of an overall revision of federal criminal statutes. ${ }^{41}$ Section two of the original act made interference with commerce by robbery or extortion a crime, while section five covered threats or commission of physical violence "in furtherance of a plan or purpose to do anything in violation of section 2."42 The present law refers to threats or violence "in furtherance of a plan or purpose to do anything in violation of this section" ;3 and the legislative history indicates that the modification of phraseology was designed not to alter substance but to effect consolidation. 44 Accordingly, threats or violence furthering a plan or purpose to obstruct commerce would not, absent robbery or extortion, appear to constitute present violations.

Apart from technical flaws, the court's construction is still objectionable. If the Nedley holding, expanding robbery, implies potential dangers to legitimate union activity, the dictum magnifies those dangers. Thus, the holding might be used to convict anyone who engaged in a sit-down strike affecting interstate

of a plant may, from a realistic standpoint, be effected in ways other than by actual entry into the building itself. It certainly is not necessary in order to constitute a seizure and holding that each and every brick and stone, each and every room and floor, be physically grasped and possessed. If the owner be deprived of the use and enjoyment of the property so that it becomes utterly valueless to him it is effectively seized and held whether the force employed for that purpose be exerted within the building or immediately without. The control of the entrances is the control of the plant." See also NLRB v. Indiana Desk Co., 149 F.2d 987 (7th Cir. 1945) (mass picketing).

37. 153 F. Supp. at 891 . See Hobbs Act $\$$ (a), note 14 supra.

38. This construction would not render the extortion clause superfluous, since extortion may rest on fear of economic reprisal. Bianchi v. United States, 219 F.2d 182, 1S8-90 (8th Cir.), cert. denied, 349 U.S. 915 (1955). However, if fear of economic loss is insufficient coercion for the robbery offense, this interpretation would make the robbery clause superfluous. See id. at 189 (dictum; fear of economic loss insufficient for robbery); note 30 supra and accompanying text.

39. 18 U.S.C. $\$ 1951$ (1952); see note 14 supra.

40. Act of July 3,1946 , c. 537,60 STAT. 420 ; see note 14 supra.

41. H.R. ReP. No. 304, 80th Cong., 1st Sess. (1947).

42. Act of July 3, 1946, c. 537, 60 Star. 420.

43. Hobbs Act § (a), note 14 supra.

44. The revision "consolidates sections $420 \mathrm{a}-420 \mathrm{e}-1$ of title 18 , U.S.C., 1940 ed., with changes in phraseology and arrangement necessary to effect consolidation." H.R. REP. No. 304, 80th Cong., 1st Sess. A131 (1947). See also United States v. Varlack, 225 F.2d 665, 672 (2d Cir. 1955). 
commerce, ${ }^{45}$ or who, in a picket line incident, stopped a truck in a way which could be deemed to give him constructive possession. ${ }^{46}$ But the dictum might even punish isolated cases of violence against nonstrikers, whether on or off the picket lines. ${ }^{47}$ While such activities are not to be condoned, punishment under the Hobbs Act, providing for sentences of up to twenty years imprisonment and $\$ 10,000$ fine, would, at the very least, discourage legitimate strikes and picketing. ${ }^{48}$

To avoid the dangers inherent in Nedley yet protect interstate commerce from obstruction, Hobbs must be narrowly construed and additional legislation enacted. Limited to extortion and robbery as defined by the common law, the Hobbs Act would bar most interferences benefitting individual labor racketeers $^{40}$ as well as union obstructions of a particularly aggravated nature. ${ }^{50}$ The states' failure to control such activities-reflected in the enactment of Hobbs-suggests that lesser offenses should also be federally proscribed. ${ }^{\text {.1 }}$ The new statute, providing smaller penalties, might be patterned on the Nedley

45. While robbery only applies to personal property, Hobbs Act § (b) (1), note 14 supra, a plant seizure could also include taking of personal property. See Apex Hosiery Co. v. Leader, 310 U.S. 469 (1940) (forcible seizure of plant and destruction of machinery). For example of sit-down strike, see NLRB v. Fansteel Metallurgical Corp., 306 U.S. 240 (1939).

46. See International Longshoremen's Union, CIO, 79 N.L.R.B. 1487, 1498 (1948) (pickets stopped car to assault nonstriker); Milk Wagon Drivers Union v. Meadowmoor Dairies, Inc., 312 U.S. 287, 291 (1941) (some trucks overturned; others driven into river).

47. For examples of violence against nonstrikers, see NLRB v. Deena Artware, Inc., 198 F.2d 645, 652 (6th Cir. 1952), cert. denied, 345 U.S. 906 (1953); Lloyd Reisner, 112 N.L.R.B. 17, 23 (1955) ; Local 1150, United Elec. Workers, CIO, 84 N.L.R.B. 972 (1949); United Furniture Workers, CIO, 84 N.L.R.B. 563, 578-82 (1949).

Evidently, the act's opponents feared just such interpretations of Hobbs. See the congressional debates on the bill, particularly the statements of Rep. Emmanuel Celler. 91 CoNg. Rec. 11899-922 (1945). See also Hearings, supra note 2, particularly the statement of Joseph A. Padway at $103-40$.

In some ways, the dictum might be more restricted than the holding, since the dictum's requirement of a plan or purpose is not necessary for conviction of robbery under the holding. Again, the dictum would not entail branding defendants as robbers or extortionists.

48. While unions need not be deterred from calling strikes, the seriousness of the statutory offense and the severity of the potential punishment could cause union members to hesitate before going on picket lines. One of the opponents of the bill admitted that "in the heat of labor disputes there will be minor altercations on the picket line" and "occasional scuffles between partisans," but feared that "under the Hobbs bill every such altercation is automatically raised to the level of a Federal offense-a Federal felony the punishment for which may be as high as 20 years in jail or $\$ 10,000$ in fine." 91 CoNG. REC. 11901 (1945) (statement of Rep. Celler). For replies by supporters of the bill, denying the validity of this interpretation, see id. at 11903.

49. See note 17 supra. The common-law element of asportation might be dispensable, but the intent to steal should be made a requisite of the offense. See notes 26,33 supra.

50. See cases cited note 19 supra.

51. See notes 6-8 supra and accompanying text. 
dictum interpreting Hobbs. ${ }^{52}$ The requirements of plan or purpose and obstruction of interstate commerce should combine to exclude cases of spontaneous violence and protect the primary jurisdiction of the states in criminal matters. ${ }^{53}$ Absent new legislation, the federal courts must either let highly undesirable activities go unpunished or seriously impede organized labor. ${ }^{4}$ Both holding and dictum in Nedley chose the latter course. The dictum so constricts legitimate union practices that, even if technically defensible, it would have to be rejected.55 The holding, based on a possible but not inevitable construction, ${ }^{56}$ serves to emphasize the dilemma of the courts and the need for legislation.

52. The penalties provided by Hobbs were determined with a view to those imposed in nonlabor robbery cases. "[I]n several States of the Union the punishment for robbery is fixed at death and ... the 20-year maximum sentence authorized by my bill is about the average." Hearings, supra note 2, at 427 (statement of Rep. Hobbs).

Assault and battery, the relevant analogy for violence cases, is subject to much smaller penalties. See, e.g., AIA. Code Ann. tit. 14, $\$ 33$ (Supp. 1955) (6 months and \$500). The new statute should similarly provide lesser penalties than Hobbs.

53. See note 6 supra; Fed. Legis., 35 Gвo. L.J. 362, 374 (1947). For an analysis of the federal-state problems involved in such criminal laws, see Boudin, The Place of the Anti-Racketeering Act in Our Constitutional-Legal System, 28 CoRNexr L.Q. 261 (1943).

54. State courts would, of course, have jurisdiction in criminal cases. But see notes 6-8 supra and accompanying text. And some cases of labor violence may be covered under Taft-Hartley as unfair labor practices. But see notes $9-13$ supra and accompanying text.

55. See note 47 supra and accompanying text.

56. See note 33 supra. 